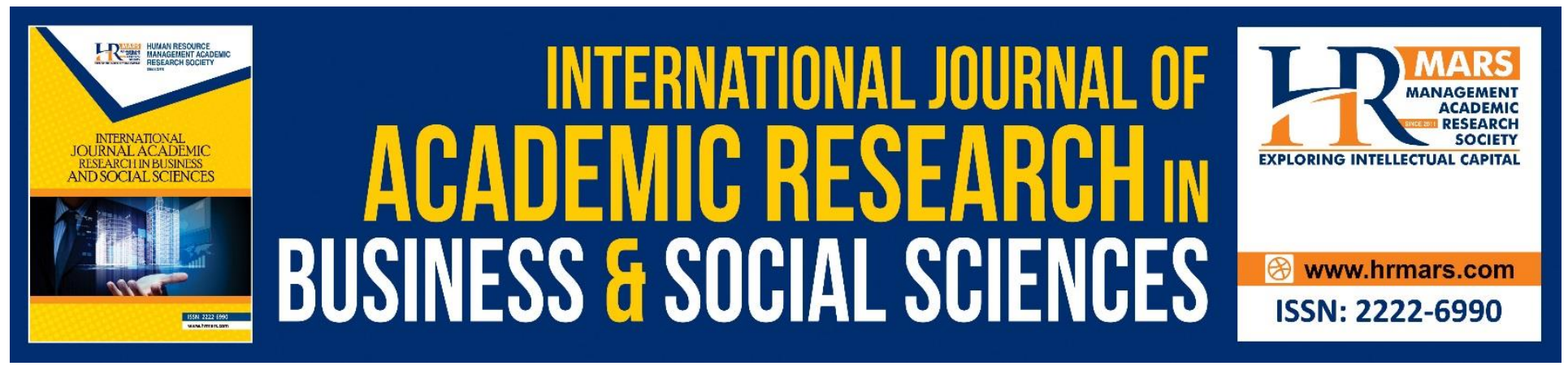

\title{
The Effect of Organizational Culture Dimensions on Organizational Development in Jordanian Public Universities
}

\author{
Moath Amin Nasaireh, Abdul Hakim Abdullah, Khaled Ahmad Obeidat
}

To Link this Article: http://dx.doi.org/10.6007/IJARBSS/v9-i1/5506 DOI: $10.6007 /$ IJARBSS/v9-i1/5506

Received: 16 Dec 2018, Revised: 29 Jan 2019, Accepted: 12 Feb 2019

Published Online: 17 Feb 2019

In-Text Citation: (Nasaireh, Abdullah, \& Obeidat, 2019)

To Cite this Article: Nasaireh, M. A., Abdullah, A. H., \& Obeidat, K. A. (2019). The Effect of Organizational Culture Dimensions on Organizational Development in Jordanian Public Universities. International Journal of Academic Research in Business and Social Sciences, 9(1), 1059-1073.

Copyright: (C) 2019 The Author(s)

Published by Human Resource Management Academic Research Society (www.hrmars.com)

This article is published under the Creative Commons Attribution (CC BY 4.0) license. Anyone may reproduce, distribute, translate and create derivative works of this article (for both commercial and non-commercial purposes), subject to full attribution to the original publication and authors. The full terms of this license may be seen at: http://creativecommons.org/licences/by/4.0/legalcode

Vol. 9, No. 1, 2019, Pg. 1059 - 1073

http://hrmars.com/index.php/pages/detail/IJARBSS

JOURNAL HOMEPAGE

Full Terms \& Conditions of access and use can be found at http://hrmars.com/index.php/pages/detail/publication-ethics 


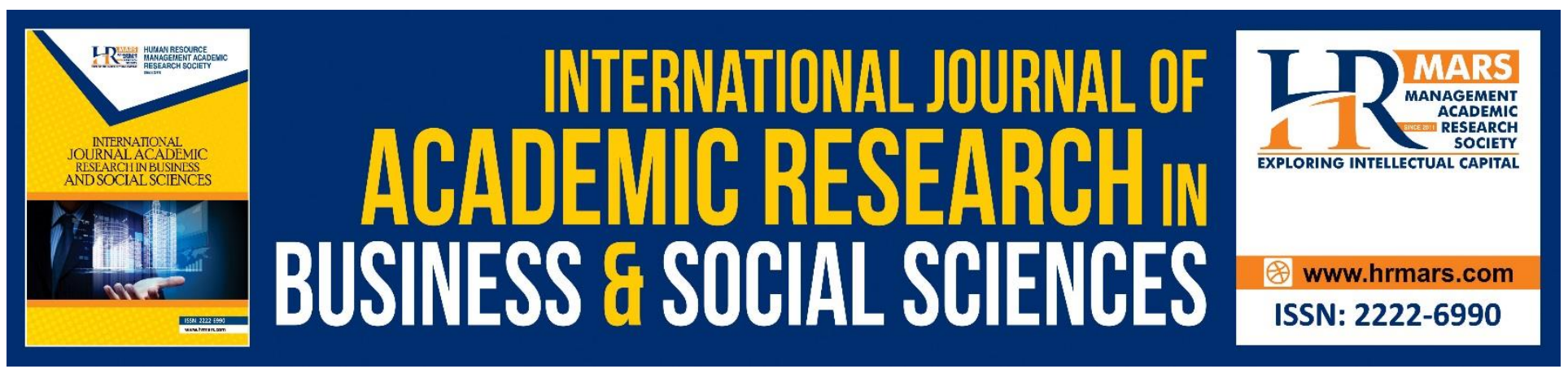

\title{
The Effect of Organizational Culture Dimensions on Organizational Development in Jordanian Public Universities
}

\section{Moath Amin Nasaireh, Abdul Hakim Abdullah, Khaled Ahmad Obeidat}

Faculty of Islamic Contemporary Studies, Universiti Sultan Zainal Abidin

E-mail: moathameen88@gmail.com,E-mail: hakimabd@unisza.edu.my,

E-mail: k.obeidat@yahoo.com

\begin{abstract}
The study explores the effect of organizational culture on organizational development in public universities in Jordan. Higher-education has a critical role in Jordan's economic growth and the future prosperity of the nation. The literature indicates the lack of attention to culture in relation to organizational development, particularly among public universities in Jordan. Very few studies have relied on quantitative research methods such as Structural Equation Modeling (SEM) in educational research to examine the different relationships among constructs in the model established on the basis of the theories. Thus, this study explored the impact of organizational culture (OC) on organizational development (OD) in Jordanian public universities. The study drew on Handy's cultural model as there has been a little research on the effect each of the four types of culture on organizational development. Accordingly, we developed and tested four hypotheses. 354 questionnaires were collected from administrative and academic members at three public universities in Jordan. This study in fact pursued a rigorous process to support the construct validity of the measure by employing EFA as well as CFA using both SPSS and AMOS-SEM. The results showed that out of the four types of culture, role culture, task culture and people culture had positive and significant impacts on organizational development, whereas power culture had a negative and insignificant effect on organizational development in Jordanian public universities. Thus, it could be concluded that higher education professionals should establish the values of organizational culture among the employees of Jordanian public universities in the higher education system in order to ensure organizational development since it could influence the whole society.
\end{abstract}

Keywords: Structural Equation Modeling (SEM), Organizational Culture, Organizational development, Jordanian public universities. 
INTERNATIONAL JOURNAL OF ACADEMIC RESEARCH IN BUSINESS AND SOCIAL SCIENCES

Vol. 9, No. 1, Jan, 2019, E-ISSN: 2222-6990 @ 2019 HRMARS

\section{Introduction}

Different types of organizations such as non-governmental, governmental, international, and political have a key role in the development of the country. In fact, they can impact the long and short term stability and development of the country. Thus, prosperous organization is an important parameter in developing the nation (Ilieş \& Gavrea, 2010). Some organizational development frameworks have been hypothesized from theories since early 1980s. The theory of Organizational Culture is one of the proposed theories. Organizational culture stresses behaviours and values that lead to the development of psychological and social environment in an organization. Needle (2004) notes that organizational culture involves the collective values, beliefs, and principles implemented by the organizational members. It is also a final product of such factors as product, history, technology, market, type of employees, strategy, national culture, and management style. Culture consists of the organization's vision, norms, values, symbols, systems, assumptions, language, habits, and beliefs. According to this theory, each organization with its own culture is fed by the concrete dimensions of the organization such as the values among members in the organization (Serpa, 2016). Organizational culture has a critical role in supporting a creative environment. It reflects the way things are practiced and is also affected by certain aspects of management such as the organizational structure, the leadership style, management of employees, and the systems of knowledge strategy (Forcadell Guadillas, 2002). Tidd et. al. (2001) argue that managing cultural change demands more development and discussion because many process innovations require main changes in the way things are practiced here. Every organization demands employees' commitment since it is a vital element in the effectiveness of an organization (Habib et al., 2014). Provide that the organizational culture enjoys a good level of flexibility, it will provide employees with such a working environment that they could work more efficiently and independently. A well-structured organization supported with a strong culture could help the members feel like they have strong role in the process (Tănase, 2015).

Higher-education in Jordan has a critical role in growing the economy of the country as well as the future prosperity of the nation. Nevertheless, educational centers in Jordan are facing challenges such as resource constraints, globalization, rapid growth of information technology, and increased competition (Al-Zawalif, 2012). They have also faced a limited financial support from the government and/or other sources in the Jordanian higher education. Innovation and initiative have been limited due to the lack of consistent long-term strategy at the universities as well as universities' slight autonomy which has been highly centralized and controlled by the Higher Education Ministry. Practicing strategic plan, research activities, and quality assurance at universities also appears to be considerably unsatisfied and slow (Batarseh, 2011). This indicates how significant it is for every university to introduce changes effectively and systematically. To do so, the universities have to make holistic and integrated efforts, which engage all the stakeholders, in order to facilitate progress and excellence in higher learning institutions. Therefore, it is crucial for the organizations to study organizational development that includes various dimensions such as organizational structure, technology (Philbin \&Mikush, 2000), strategic change management (Degnegaard, 2010), and human resource management (Cummings Worley, 2014). As a result, there is a urgent need for organizational development among both organizations and individuals to overcome these problems, to help organizations survive and gain its goals effectively and efficiently. more importantly, 
INTERNATIONAL JOURNAL OF ACADEMIC RESEARCH IN BUSINESS AND SOCIAL SCIENCES

Vol. 9, No. 1, Jan, 2019, E-ISSN: 2222-6990 (C) 2019 HRMARS

organizational culture impacts organizations and the way they approach problems and their adaptation to their environment. Therefore, their success in the global operations requires organizations to know the cultures that they are carrying on business with (Sabri, 2015).

Based on the literature review regarding organizational culture conducted prior to this study it became apparent that much of the research conducted has thus far has not been primarily conducted by scholars in the academic organization's field (Alattas \& Kang, 2015; Isa, Ugheoke, \& Noor, 2016; Mohd Izhan, 2015; Umrani, 2016). As a result of this finding this work assumes that, of the interventions and research conducted, little has been conducted by practitioners of the organizational development field especially in the context of whole systems approaches to these institutions. Accordingly, the present study aimed at examining the impact of organizational culture on organizational development in Jordanian public universities. In doing so, this study used Handy's cultural model since limited efforts have been made to explore the effect each of the four kinds of culture on organizational development.

The present study tries to answer the following research questions:

- What is the impact of power culture on organizational development in Jordanian public universities?

- What is the impact of role culture on organizational development in Jordanian public universities?

- What is the impact of task culture on organizational development in Jordanian public universities?

- What is the impact of people culture on organizational development in Jordanian public universities?

\section{Literature Review}

\section{Organizational Development}

Organizational development is a change approach based on a specific to assist organizations to improve and grow their efficiency (McLean, 2005). Organization development has been accepted as a typical terminology in management studies since 1960. Although, organization development has not been specifically defined or explained as a field in the dictionaries or the Encyclopedia Britannica, it has endured some turbulent times and it will be widely used for the predictable future. Although not defined in the popular dictionaries, the Encyclopedia of Management Theory has provided a clear definition for organization development (Burke, Noumair, 2015). According to French and Bell (1973), organizational development is a sustained effort to advance the organization's renewal and problemsolving, especially through a more collaborative and competent management of organization culture with particular emphasis on the members' culture, with the help of a change catalyst or agent, and the adoption of technology and theory. on the other hand, Brown and Harvey (2006) define organizational development as a long-term endeavor by an organization to deal with change, address and solve problems, and renewing itself via an efficient management. according to these definitions, organizational development is in fact a prerequisite for any organizations and it is derived from the demand of the cultural change in each period and raises social awareness. 
Further, Philbin and Mikush (2000) refer to organizational development as the process through which an organization undergoes in order to increase the internal capacity to perform effectively in its mission and to survive over the long term. This definition reflects the obvious association between the success of an organizational mission and organizational development process.

\section{The Importance of Organizational Development}

Organizational development has a vital role in helping an organization survive in a dramatically changing world (Blair et al., 2002). It is a field of study which addresses changes and how they impact the organization as well as its members. Effective organizational development could help organizations and individuals to deal with change. Strategies could be created to make team-building efforts, a well-planned change, and the practices of organization. Over the last years, organizational development has steadily grown and been geared towards solving problems in organizations. It surely is a significant element in improving and changing organizations. Schien (1992) notes that organizational development is as a planned change process which is managed from the top and that it needs to consider both the human and the technical aspects of the organization. Organizational development has its origin in sociology, psychology and intensive studies conducted by many researchers; its primary concern is to know organizations and their members.

Concerning the key role of organizational development in educational organizations, the literature usually emphasizes the major contribution of organizational development to education. However, there is a still a debate over how organizational development could function and what are its basic elements. This debate is more critical among educational organizations which are supposed to be more open to learning and development as compared to other organizations (Kilmann, 2001).

\section{Organizational Culture}

The term culture was derived from a Latin world colere or culture and it means growing, cultivating, and caring. The first academic research on organizational culture could be dated back to 1930s (Durgun, 2006). However, formal writing on culture was done by Pettigrew (1979) who first introduced the concept of anthropology in the study of culture and showed how interrelated concepts such as myth, symbolism, and rituals could be employed in the organizational analysis (Lee $\& \mathrm{Yu}, 2004)$. Since then, the concept of organizational culture has been widely adopted by researchers (Aksoy et al., 2014).

Organizational culture has been described from various aspects (Abu-Jarad et al., 2010; Schneider et al., 2013). For instance, Geert et al. (2010) view organizational culture as a process that help produce one member from another based on cognitive thinking. According to Schein (2004), on the other hand, Organizational culture is the success guidance on the basis of various norms and values which make culture effective in gaining the organization goals. Further, Kotter et al. (1992) refers to organizational culture as the set of behaviour, beliefs, values, and norms which contribute to organizational effectiveness. Organizational culture is also considered as a system of values, assumptions, attitudes, and norms shown via symbols. The organization members need to adopt and develop such a system through mutual experience. It assists them to find the meaning of the world around them and how to perform in it (Janicijevic, 2011). Aksoy et al. (2014) note that the 
organizational culture is a set of values which are formed not only by the behaviors and manners of every single member in the organization but also by the behavior and collective attitudes of the organization in total. Aktas et al. (2011) also described it as a set of values, norms, attitudes, and belief that impact organizational behavior. Therefore, we view organizational culture as a fundamental pattern of shared beliefs, values, and assumptions which are regarded to be the appropriate way of considering and acting on opportunities and problems in the organization.

\section{The Importance of Organizational Culture}

organizational culture is one of the most critical elements that affect organizational development. Organizational culture teaches the individuals to learn, feel, and establish the principles, patterns, expectation, norms, and behaviour which increase high levels of achievements by helping find the desired solutions (Schein, 1992; Armstrong, 2006). Organizational culture comprised of crucial unstated assumptions that members of an organization have in common. The main and common assumptions are beliefs and values. Beliefs are concerned with assumptions about reality and have root in and strengthened by experience. On the other hand, values pertain to assumptions about ideals which are worth striving for and desirable (Muya \& Wesonga, 2012). Organizational culture is so critical since it is the most fundamental parameter in defining an organization. Many organizations' members define their organization this way. Nowadays, business environment is so demanding due to its quick fluctuating demands which cause many corporate and mergers to restructure, thus causing the most employees to feel unimportant in the process of chain management. A wellstructured organization, which benefits from a strong culture, could help the employees to feel their vitality in management process. A strong culture is as critical as having the knowledge of when a change is required. Every employee has to adopt a proactive approach and to do their jobs side by side with the other members so that a desirable and successful change of organizational culture occur. The result of such a change is proper solutions which assist the organization to change according to a certain plan and also to begin a new expected growth period which appears due to the change. The main goal of all of this is that the organization thrives and reaches its objectives and this is possible when values and rules are firmly established and followed within the organization. Accordingly, we perceive the significance of values in organizational culture (Tanase, 2015).

\section{Dimensions of Organizational Culture}

Many typologies have been proposed for organizational cultures by different researchers (Schein, 1990; Cole, 1997; Wallach, 1983; Hofstede, 1980; Denison, 1990; O'Reilly et al., 1991; Schwartz, 1981). Handy (1996) classifies four types of organizational cultures: power culture, role culture, task culture, and people culture (Davidson, 2003). Power culture is concerned with to what extent a main character (i.e. a leader) impacts others members in an organization. Role culture, which is bureaucratic in nature, defines how work is to be planned and process to be followed in order to carry out tasks successfully. This organizational culture does not advocate using initiative in doing duties. Task culture is considered a job-centered organizational culture because the organization effectiveness is known on the basis the expertise level of the central figure compared to personal authority. People culture, known as individual centered, is based on the idea that an organization has come to help individuals and not vice versa. Thus, this study relied on Handy's cultural model since 
INTERNATIONAL JOURNAL OF ACADEMIC RESEARCH IN BUSINESS AND SOCIAL SCIENCES

Vol. 9, No. 1, Jan, 2019, E-ISSN: 2222-6990 (C) 2019 HRMARS

limited efforts have been made to study the effect of each of the four types of culture on organizational development.

\section{Research Methodology}

The research method used is quantitative, and using research instruments based on the Learning Inventory model in the School developed by Selmes (1987). The questionnaire items have been adjusted according to the suitability of the learning system in SMA. Data were analyzed using Structural Equation Modeling (SEM) with IBM-SPSS-AMOS program version 21.0. SEM is formed with two main models namely measurement model and Structural model. Before the SEM test is tested, prior adjustment tests should be made to ensure that the tested indicator actually represents the measured construction. There are two main analyzes that were applied before the SEM analysis is performed: (1) Exploration Analysis Factor (EFA), and (2) Confirmation Factor Analysis (CFA). Validation factor analysis (CFA) is a test of measurement model to ensure that each construction meets procedures such as validity and reliability for each experiment being built (Kline, 2016; Awang, 2015; Chua, 2014d; Byrne; 2013; Hair et al., 2006; Schumucker \& Lomax, 2004). Comparison of model measurement is essential to ensure that any latent construction in this study is compatible with the data studied before SEM can be continued (Kline, 2016; Awang, 2015; Schumucker \& Lomax, 2004).

The structural model is considered to be in accordance with the research data when the chisq/df value is less than 5.0 (Marsh and Hocevar, 1985). The structural model is also considered to correspond to a GFI value greater than 0.90 (Joreskog and Sorbom, 1993). The value of RMSEA is very good if it is smaller than 0.08 (Hair et al., 2006; Browne \& Cudeck, 1993), but still less than 0.1 (Byrne, 1998, 2013). Bentler (1990) also recommends receiving CFIs over 0.90. But the CFI value between 0.80 and 0.89 is still at the margin received. To verify the model developed, the boostrapping value is determined. According to Bollen \& Stine (1992), the developed model is considered to have validity when the bootstrap value exceeds 0.05 means there is no difference between the data collected from the sample with the proposed model. Therefore, the proposed model is valid based on data collected from the research sample.

\section{Research Findings}

Analysis of the Impact between Building Power Culture, Role Culture, Task Culture and People Culture

The SEM Procedure provides two types of output namely graph output and text output. There are two types of graphical output i.e. showing the standard regression value between the constructs and also showing the regular regression values. Both have their own uses. Figure 1 shows the standard regression weight findings while Figure 2 shows the typical regression value as a result of the SEM procedure. The formulas of both output types are described in detail. 


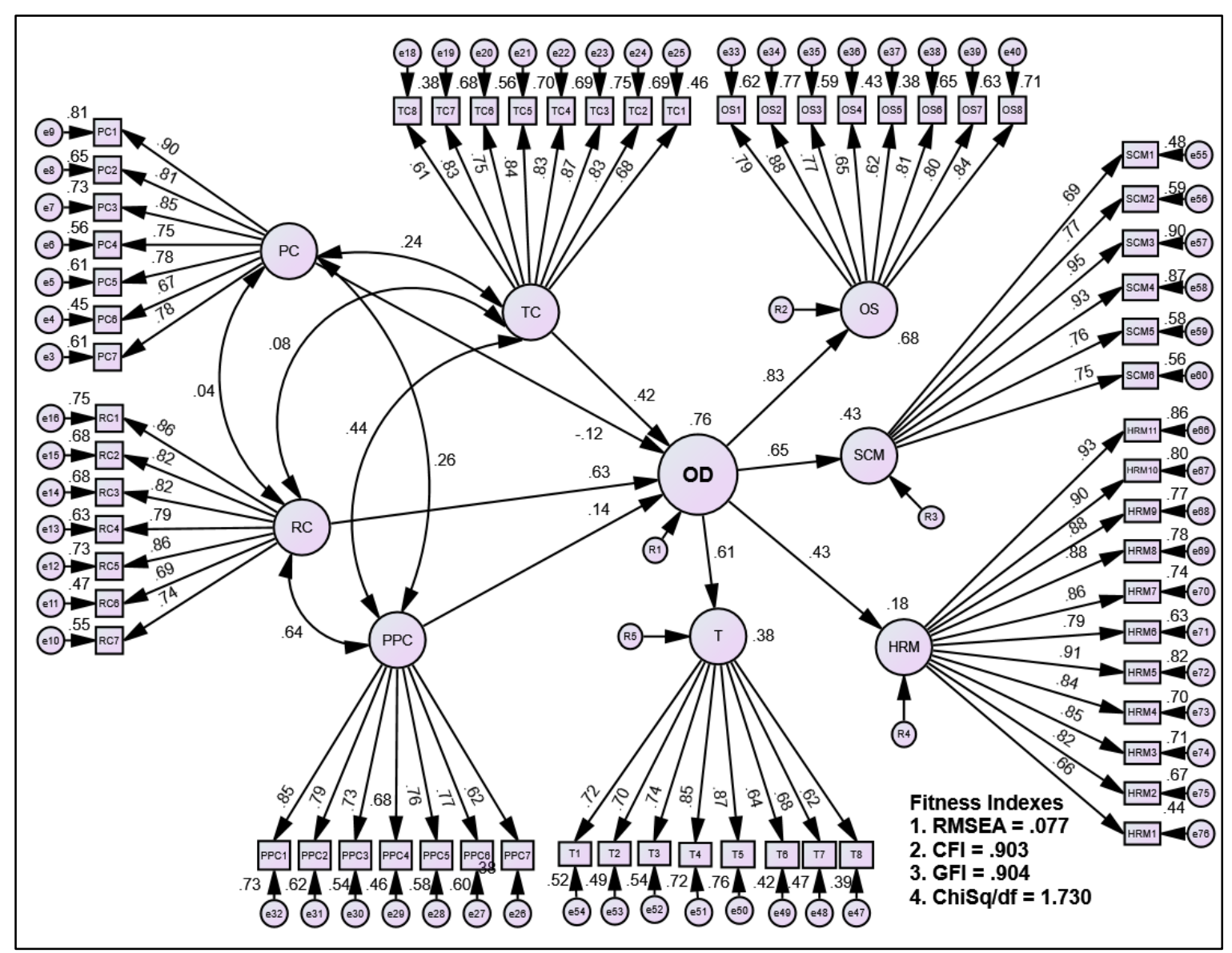

Figure 1: SEM Findings Shows the Standard Regression Value between Constructs

1) An important summary of the SEM findings in Figure 1 (standard regression):

a) The $R^{2}$ value for the "Organizational Development" (OD) construct is 0.76 . This shows four predictor constructs in the model (see arrows) namely "Power Culture" (PC), "Role Culture" (RC), "Task Culture" (TC) and "People Culture" (PPC) contributed $76 \%$ to " Organizational Development " (OD) population in the study.

b) The correlation value between the two free constructs in the model shown by doubleheaded arrows is as follows: The correlation between PC and TC is $0.24, \mathrm{PC}$ and RC is 0.04, PC and PPC is 0.26, TC and RC is 0.8, TC and PPC is 0.44 and RC and PPC is 0.64 . This shows that the SEM model is valid and has no multicollinearity problem.

Figure 2 shows the findings of the regression value between the constructs in the model, to construct the required regression equation and make hypothesis testing later. 


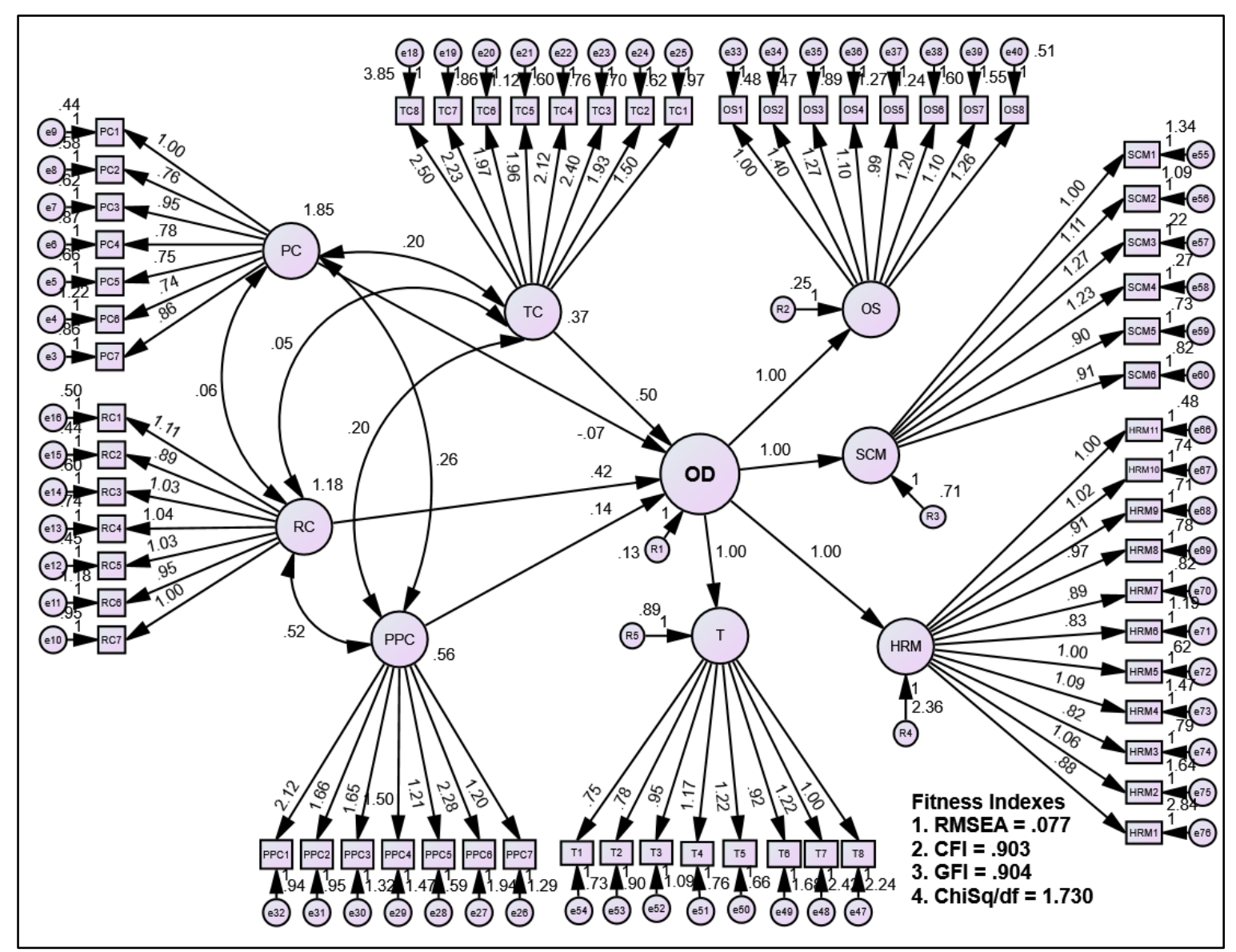

Figure 2: SEM findings show regression values between constructs

2) Essential summaries of SEM findings in Figure 2 (regression value):

The regression equation for Organizational Culture $(O C)$ and Organizational Development (OD) are as follows:

a) $\mathrm{OD}=0.50 \mathrm{TC}+(-0.07) \mathrm{PC}+0.42 \mathrm{RC}+0.14 \mathrm{PPC}\left(\mathrm{R}^{2}=0.76\right)$

The researcher then test each hypothesis proposed in this study. Table 1 shows the estimates of the direct effects of the effects of each independent construct on the constructs in the model as shown in Figure 2 above. 
INTERNATIONAL JOURNAL OF ACADEMIC RESEARCH IN BUSINESS AND SOCIAL SCIENCES Vol. 9, No. 1, Jan, 2019, E-ISSN: 2222-6990 @ 2019 HRMARS

Table 1: Regression Coefficients between Constructs and Probability Values (p)

\begin{tabular}{|c|c|c|c|c|c|c|c|}
\hline Construct & & Constructs & Estimate & S.E. & C.R. & P & Label \\
\hline OD & $<---$ & TC & 0.957 & 0.120 & 7.956 & 0.001 & Significant \\
\hline OD & $<---$ & PC & -0.067 & 0.046 & -1.456 & 0.146 & Not Significant \\
\hline OD & $<---$ & RC & 1.026 & 0.117 & 8.753 & 0.001 & Significant \\
\hline OD & $<---$ & PPC & 0.398 & 0.094 & 4.221 & 0.001 & Significant \\
\hline
\end{tabular}

$* * *$ Significant value at the level of significance, $p<0.001$

The Table 2 shows the results of hypothesis testing of direct effects of free constructs on dependent constructs. The hypothesis testing in Table 2 is based on SEM findings from Figure 1 above.

Table 2: Hypothesis Testing of Direct Impact between Constructs

\begin{tabular}{|c|c|c|}
\hline Hypothesized Path (Direct Effect Hypothesis) & $\mathbf{P}$ & Decision \\
\hline $\begin{array}{l}\mathrm{H}_{1}: \text { Power culture has a significant impact on organizational } \\
\text { development in Jordanian public universities. }\end{array}$ & 0.146 & $\begin{array}{c}\text { Not } \\
\text { Supported }\end{array}$ \\
\hline $\begin{array}{l}\mathrm{H}_{2}: \text { Role culture has a significant impact on organizational } \\
\text { development in Jordanian public universities. }\end{array}$ & 0.001 & Supported \\
\hline $\begin{array}{l}\mathrm{H}_{3}: \text { Task culture has significant impact on organizational } \\
\text { development in Jordanian public universities }\end{array}$ & 0.001 & Supported \\
\hline $\begin{array}{l}\mathrm{H} 4: \text { People culture has a significant impact on organizational } \\
\text { development in Jordanian public universities. }\end{array}$ & 0.001 & Supported \\
\hline
\end{tabular}

\section{Impact of Power Culture on Organizational Development}

Table 1 shows that Power culture has a significant impact on organizational development in Jordanian public universities with regression value estimation $(\beta)$ is -0.067 at significant level of 0.146 (Estimation=-0.067, $C R=-1.456, p<0.001$ ). This means that the Power Culture has no positive and not insignificant influence on the organizational development. The findings of this study indicate that the construction of Power Culture has no positive and not insignificant effect on the construction of Organizational Development.

\section{Impact of Role Culture on Organizational Development}

Table 1 shows that Role culture has a significant impact on organizational development in Jordanian public universities with estimated regression value $(\beta)$ is 1.026 at significant level 0.001 (Estimate $=1.026, C R=8.753, p<0.001$ ). This means that the construction of Role Culture has a positive and significant influence on the construction of Organizational Development. This means that if the Role Culture increased by 1 unit, Organizational Development will increase by 1.026 units. The findings of this study indicate that the construct of Role Culture has a positive and significant influence on the organizational development in Jordanian public universities.

\section{Impact of Task Culture on Organizational Development}

Table 1 shows that Task culture has a significant impact on organizational development in Jordanian public universities with estimated regression value $(\beta)$ is 0.957 at significant level 0.001 
(Estimate $=0.957, C R=7.956, p<0.001$ ). This means that the construction of Task Culture has a positive and significant influence on the construction of Organizational Development. This means that if the Task Culture increased by 1 unit, Organizational Development will increase by 0.957 units. The findings of this study indicate that the construct of Task Culture has a positive and significant influence on the organizational development in Jordanian public universities.

\section{Impact of People Culture on Organizational Development}

Table 1 shows that People culture has a significant impact on organizational development in Jordanian public universities with estimated regression value $(\beta)$ is 0.398 at significant level 0.001 (Estimate $=0.398, C R=4.221, p<0.001$ ). This means that the construction of People Culture has a positive and significant influence on the construction of Organizational Development. This means that if the People Culture increased by 1 unit, Organizational Development will increase by 0.398 units. The findings of this study indicate that the construct of People Culture has a positive and significant influence on the organizational development in Jordanian public universities.

\section{Conclusion}

Overall, the hypotheses were tested. The carried out on the Inference analysis findings show Role Culture, Task Culture and People Culture, have a positive and significant impact on organizational development in Jordanian public universities, but the Power Culture has no positive and not significant impact on the organizational development. However, this study has practical implications for the Jordanian public universities and academic and administrative members. Thus, it could be concluded that should establish the values of organizational culture among the employees of Jordanian public universities in order to ensure organizational development since it could influence the whole society.

\section{Acknowledgement}

Special appreciation is owed to prof Abdul Hakim Abdullah and Universiti Sultan Zainal Abidin (UniSZA), Research Management, Innovation \& Commercialization Centre (RMIC) UniSZA.

Corresponding Author: Moath Amin Nasaireh, Faculty of Islamic Contemporary Studies, Universiti Sultan Zainal Abidin, Gong Badak Campus, 21300 Kuala Terengganu, Terengganu, Malaysia.

Email: moathameen88@gmail.com

\section{References}

- Abu-Jarad, I. Y., Yusof, N. A., \& Nikbin, D. (2010). A review paper on culture and organizational performance. International Journa

of $\begin{gathered}\text { organizational } \\ \text { Business and }\end{gathered}$ Social Science, 1(3).

- Aksoy, M., Apak, S., Eren, E., \& Korkmaz, M. (2014). Analysis of the effect of Organizational learning-based Organizational Culture on Performance, Job Satisfaction and Efficiency: A Field Study in Banking Sector. International Journal of Academic Research, 6(1).

- Aktaş, E., Çiçek, I., \&Kıyak, M. (2011). The effect of organizational culture on 
INTERNATIONAL JOURNAL OF ACADEMIC RESEARCH IN BUSINESS AND SOCIAL SCIENCES

Vol. 9, No. 1, Jan, 2019, E-ISSN: 2222-6990 @ 2019 HRMARS

organizational efficiency: The moderating role of organizational environment and CEO values. Procedia-Social and Behavioral Sciences, 24, 15601573.

- Alattas, M., \& Kang, K. (2016). The relationship between organization culture and knowledge sharing towards business system success. arXiv preprint arXiv:1606.02460.

- Al-Zwyalif, I. M. (2012). The Possibility Of Implementing Balanced Scorecard in Jordanian Private Universities. International Business Research, 5(11): $\quad 113$.

- Armstrong, M. (2006). A Handbook of Human Resource Management Practice ed.).Kogan Page, London and Philadelphia, PA.

- Awang, Z. (2015). SEM Made Simple: A Gentle Approach to Learning Structural Equation Modeling. Bandar Baru Bangi, MPWS Rich Resources.

- Batarseh, I. (2011). Quality of higher education in Jordan. In lecture, 22nd International conference on higher education: Quality in higher education, Ankara, Turkey, delivered (Vol. 17).

- Bentler, P. M. (1990). Comparative fit indexes in structural models. Psychological bulletin, 107(2), 238.

- Blair, M., Sorensen, P. \& Yaeger, T. (2002). OD Practitioner. Journal of the Organization Development Network, 34(1), http://www.odnetwork.org/odponline/vol34n1/ fromtheeditors.html

- Bollen, K. A., \& Stine, R. A. (1992). Bootstrapping goodness-of-fit measures in structural equation models. Sociological Methods and Research, 21, 205-229.

- Brown, D.R. and Harvey, D.F. (2006). An experiental approach to organization development (7th edt.). USA: Pearson Prentice Hall.

- Brown, M. W., and R. Cudeck. (1993). Alternative Ways of Assessing Model Fit. Sage focus editions, 154, 136-136.

- Burke, W. W., \& Noumair, D. A. (2015). Organization development: A process of learning and changing. FT Press.

- Byrne, B. M. (1998). Structural equation modeling with LISREL, PRELIS and SIMPLIS: Basic concepts, applications and programming. Mahwah, New Jersey: Lawrence Erlbaum Assiociates.

- Byrne, B. M. (2013). Structural equation modeling with AMOS: Basic concepts, applications, and programming (2nd ed.). New York: Routledge.

- Chua, Y. P. (2014d). Kaedah dan statistik penyelidikan: Ujian regresi, analisis faktor, dan analisis SEM, Buku 5 (edisi 2). Selangor: McGraw-Hill Education (Malaysia) Sdn. Bhd.

- Cole, G.A., (1997). Personnel Management, 4 ed. Letts Educational, London.

- Cummings, T. G., \& Worley, C. G. (2014). Organization development and change. Cengage learning.

- Degnegaard, R. (2010). Strategic change management. Change Management Challenges in the Danish Police Reform. København: Copenhagen Business School. 
- Denison, D. R. (1990). Corporate culture and organizational effectiveness. New York: John Wiley \& Sons.

- Durğun, S. (2006). Örgüt kültürü ve örgütsel iletişim. Yüzüncü Yıl Üniversitesi Eğitim Fakültesi Dergisi, 3(2), 112-132.

- Forcadell, F. J., \& Guadamillas, F. (2002). A case study on the implementation of a knowledge management strategy oriented to innovation. Knowledge and Process Management, 9(3), 162-171.

- French, W. L., \& Bell, C. H. (1973). Organization development: Behavioral science interventions for organization improvement (p. xiii). Englewood Cliffs, NJ: Prentice-Hall.

- Geert, Hofstede \& Gert Jan Hofstede \& Michael Minkov (2010). Cultures and Organizations.

- Habib, S., Aslam, S., Hussain, A., Yasmeen, S., \& Ibrahim, M. (2014). The Impact of Organizational Culture on Job Satisfaction, Employess Commitment and Turn over Intention. Advances in Economics and Business, 2(6), 215-222.

- Hair, J. F., Black, W. C., Babin, B. J., Anderson, R. E., \& Tatham, R. L. (2006). Multivatiate data analysis (6th ed.). New Jersey: Pearson Education International.

- Handy, C. B. (1996). Gods of management: The changing work of organizations. Oxford University Press, USA.

- Hofstede, G. (1980). Culture and organizations. International Studies of Management \& Organization, 10(4), 15-41.

- Ilieş, L., \& Gavrea, C. (2010). The Role Of Organizational Diagnosis In Improving Firm Performance.

- Isa, M. F. M., Ugheoke, S. O., \& Noor, W. S. W. M. (2016). The influence of organizational culture on employees' performance: evidence from Oman. Journal of Entrepreneurship and Business, 4(2), 1-12.

- Janićijević, N. (2011). Methodological Approaches in the Research of Organizational Culture. Economic Annals, 46 (189), pp. 69-100.

- Kilmann, R. H. (2001). Quantum Organizations: A New Paradigm for Achieving Organizational Success and Personal Meaning (California: Davis).

- Kilmann, R. H. (2001). Quantum Organizations: A New Paradigm for Achieving Organizational Success and Personal Meaning (California: Davis).

- Kline, R. B. (2016). Principles and practice of structural equation modeling (4th ed.). New York: The Guilford Press.

- Kotter, E. H., \& Heskett, O. K. (1992). Culture: The Missing Concept in Organizational Studies. Administrative Science Quarterly, 4(2), 229-240.

- Lee, S. K. J., \& Yu, K. (2004). Corporate culture and organizational performance. Journal of Managerial Psychology, 19(4), 340-359.

- Marsh, H. W., \& Hocevar, D. (1985). Application of confirmatory factor analysis to the study of selfconcept: First-and higher order factor models and their invariance across groups. Psychological bulletin, 97(3), 562. 
- McLean, G. N. (2006). Organization development: Principles, processes, performance. San Francisco: Berrett-Koehler.

- Mohd Izhan, I. (2015). The effect of the environmental, organization culture factors on job satisfaction study of Royal Malaysian Police (Doctoral dissertation, Universiti Utara Malaysia).

- Muya, J. N. and Wesonga J. N. (2012). The Impact of Organizational Culture on Performance of Educational Institutions, International Journal of Business and Social Science, 3(8), 211-217.

- Needle, D. 2004. Business in Context: An Introduction to Business and Its Environment. Hampshire: South-Western Cengage Learning.

- O'Reilly, C. A., Chatman, J., \& Caldwell, D. F. (1991). People and organizational culture: A profile comparison approach to assessing person-organization fit. Academy of management journal, 34(3), 487-516.

- Pettigrew, A. M. (1979). On studying organizational cultures. Administrative science quarterly, 24(4), 570- 581.

- Philbin, A., \& Mikush, S. A. (2000). A Framework for organizational development: The why, what, and how of OD work. Winston-Salem, NC: Mary Reynolds Babcock Foundation.

- Sabri, H. (2015). Designing the Structure in similar Cultures: A comparative study between Japan and Jordan. International Journal of Business and Management, 3(4), 122-142.

- Schein, E. H. (1990). Organizational culture (Vol. 45, No. 2, p. 109). American Psychological Association.

- Schein, E. H. (1992). How can organizations learn faster?: the problem of entering the Green Room. Alfred P. Sloan School of Management, Massachusetts Institute of Technology.

- Schneider, B., Ehrhart, M. G., \& Macey, W. H. (2013). Organizational climate and culture. Annual review of psychology, 64, 361-388.

- Schumucker, R. E. \& Lomax, R. (2004). A beginner's guide to structural equation modeling (2nd ed.). Mahwah, New Jersey: Lawrence Erlbaun Associates Publishers.

- Schwartz, H., \& Davis, S. M. (1981). Matching corporate culture and business strategy. Organizational dynamics, 10(1), 30-48.

- Serpa, Sandro.(2016).An Overview Of The Concept Of Organizational Culture. International Business Management,10(1): 51-62.

- Tănase, I. A. (2015). The importance of organizational culture based on culture transfer.". Management and Innovation for Competitive Advantage.

- Taşdelen, T. Y., \& Polat, M(2015). Organizational Development and Quantum Organizations.

- Tidd, J., Bessant, J. R., \& Pavitt, K.(2001). Managing Innovation: Integrating Technological, Market and Organizational Change, Wiley.

- Umrani, W. A. (2016). Moderating effect of organizational culture on the relationship between corporate entrepreneurship and business performance in Pakistan's banking sector (Doctoral dissertation, Universiti Utara Malaysia). 
INTERNATIONAL JOURNAL OF ACADEMIC RESEARCH IN BUSINESS AND SOCIAL SCIENCES Vol. 9, No. 1, Jan, 2019, E-ISSN: 2222-6990 @ 2019 HRMARS

- Wallach, E. J. (1983). Individuals and organizations: The cultural match. Training and Development Journal, 37(2), 29-36. 